\title{
$\widehat{A}$ Madridge
}

madridge Journal of Aquaculture Research \& Development

\author{
Interconnecting Scientific World
}

Research Article

Open Access

\section{Effect of Dietary Supplementation of Vitamin C and Seeds of Achyranthes aspera on Growth, Digestive Enzyme Activities, Immune System and Lipid Peroxidation of Snow Trout Schizothorax richardsonii}

\author{
Moses Rinchui Ngasainao ${ }^{1}$, Kjell J Nilssen ${ }^{2}$ and Rina Chakrabarti ${ }^{3 *}$ \\ ${ }^{\prime}$ Department of Zoology, Deshbandhu College, University of Delhi, Delhi, India \\ ${ }^{2}$ Department of Biological Science, Norwegian University of Science and Technology, Trondheim, Norway \\ ${ }^{3}$ Aqua Research Lab, Department of Zoology, University of Delhi, Delhi 110007, India
}

\section{Article Info}

*Corresponding author:
Rina Chakrabarti
Aqua Research Lab
Department of Zoology
University of Delhi
Delhi 110007, India
Email: aquaresearchlab@yahoo.co.in

Received: May 22, 2017

Accepted: June 13, 2017

Published: June 20, 2017

Citation: Ngasainao MR, Nilssen KJ, Chakrabarti R. Effect of Dietary Supplementation of Vitamin C and Seeds of Achyranthes aspera on Growth, Digestive Enzyme Activities, Immune System and Lipid Peroxidation of Snow Trout Schizothorax richardsonii. Madridge J Aquac Res Dev. 2017; 1(1): 24-30.

doi: $10.18689 / \mathrm{mjard}-1000105$

Copyright: @ 2017 The Author(s). This work is licensed under a Creative Commons Attribution 4.0 International License, which permits unrestricted use, distribution, and reproduction in any medium, provided the original work is properly cited.

Published by Madridge Publishers

\begin{abstract}
Nutrition plays significant role in the survival, growth and physiology of fish. Snow trout Schizothorax richardsonii larvae were cultured under three feeding regimes: control $\operatorname{diet}(\operatorname{diet} \mathrm{D} 1)$ and test diets, supplemented with vitamin C ( $800 \mathrm{mg} / \mathrm{kg}$ diet, diet D2) and Achyranthes aspera seeds (5 g/kg diet, diet D3). There was no significant $(P>0.05)$ difference in the survival rate of larvae cultured under three different feeding regimes. Significantly $(P<0.05)$ higher average weight and specific growth rate and lower food conversion ratio were found in D3 diet fed larvae compared to others. Amylase, total protease, trypsin and lipase activities were significantly $(P<0.05)$ higher in D3 diet fed larvae and chymotrypsin activity was significantly $(P<0.05)$ higher in D2 diet fed larvae compared to others. Dietary supplementation of vitamin $C$ and Achyranthes aspera seeds improved immune system as myeloperoxidase and nitric oxide synthase levels were significantly $(P<0.05)$ higher in enriched diets fed larvae compared to the control one. Reduced lipid peroxidation was recorded in enriched diets fed larvae as thiobarbituric acid reactive substances level was significantly $(P<0.05)$ lower in D2 and D3 diets fed larvae compared to the control diet fed larvae.
\end{abstract}

Keywords: Schizothorax richardsonii; Achyranthes aspera; Vitamin C; Digestive enzymes; Myeloperoxidase; Lipid peroxidation.

\section{Introduction}

Schizothorax richardsonii (Gray) is an important food fish of the Himalayan region. So far fish were harvested from the natural resources. Development of proper husbandry is required for the sustainable aquaculture development in the hill region. Considerable emphasis has been given for the development of reproductive techniques viz. induced breeding, artificial fertilization, egg rearing, hatching and semen cryopreservation for snow trout species [1] [2] [3] [4] [5]. Though artificial propagation of snow trout through induced breeding has been successful [1] [3], rearing of snow trout larvae under controlled condition is still less explored. The major bottleneck in culturing snow trout has been reported to be slow growth rate and poor disease resistance capacity [6] along with shortage of current literature on snow trout nutritional aspect.

Inadequate nutritional and culture conditions attribute slow growth rate and poor disease resistance in many farmed fish. Hence, supply of proper diet is a necessity in 
preserving animal's health and maintaining its ability to resist the disease [7]. Snow trout being a teleost, lacks the enzyme L-gulono-lactone oxidase which is responsible for the endogenous synthesis of ascorbic acid (AA) from L-gulonolacetone in liver and kidney [8]. Hence, dietary supplementation of vitamin $C$ is necessary to improve immunomodulatory properties [9] [10], metabolic antioxidant function [11]. It serves as a cofactor in the hydroxylation of proline and lysine in collagen synthesis [12]. Vitamin C has been used in feed for improving fish immunity and growth [13] [14], reproduction and health [15] [16] and tissue protection against UV-B radiation [17].

Dietary supplementation of plant ingredients as immunostimulants to modulate the non-specific immune system of fish or prophylactic measure against disease [18] has become an important area in aquaculture to avoid the ill effect of use of antibiotics. Achyranthes aspera L. (family: Amaranthaceae) is considered as a medicinal plant, used traditionally in treating fever, especially malarial fever, dysentery, asthma, hypertension and diabetes [19] [20] in humans. Incorporation of plant ingredients in diets enhanced the survival rate, growth and disease resistance in carps Catla catla, catla [21], Labeo rohita, rohu [22] and Cyprinus carpio, common carp [23].

Most of the growth performance studies in snow trout have been conducted with grow-out stage [24] [25] [26] [27] and brooders [28]. Review of literature shows that there is dearth of information on the physiology of larval period, especially the digestive enzyme profile; information related to larval immune system is also not available. Small differences in early growth and survival rates can affect the number of recruits entering the adult stock [29] [30]. Haematological parameters are good indicators of health status of fish and therefore, are important in diagnosing the structural and functional status of fish exposed to toxicant [31]. Myeloperoxidase is an abundantly expressed lysosomal protein stored in neutrophil. Release of myeloperoxidase by neutrophils and monocytes during inflammation plays an important role in the innate immune response [32].

The amino transferases, aspartate aminotransferase (SGOT) and alanine aminotransferase (SGPT) are usually found in different tissues viz. liver, muscles, kidney etc. Elevated amount of these amino transferases are indicators of tissue damage. Nitric oxide synthase are a family of enzymes that catalyze the production of cellular signalling molecule nitric oxide. This nitric oxide plays vital role in many biological processes. Oxidation of lipid shows the free radical-induced damaged to aquatic organisms. Elevated amount of thiobarbituric acid reactive substances (TBARS) is an indicator of lipid peroxidation in tissues. The knowledge of digestive enzyme profile (viz. amylase, total protease, trypsin, chymotrypsin and lipase) and immune system of larvae is required for the development of proper culture technique of a new aquaculture species. This will enhance the survival rate, promote growth and help in the production of healthy, disease free stocks. Therefore, the present study aimed to evaluate the effect of vitamin $C$ and Achyranthes aspera seeds enriched diets on the digestive enzyme profile, immune system and lipid peroxidation of snow trout Schizothorax richardsonii (family: Cyprinidae) larvae.

\section{Materials and Methods Source and culture of larvae}

Snow trout Schizothorax richardsonii larvae were collected from Gandi River, Champawat, Uttrakhand (29 $20^{\prime} 44^{\prime \prime} \mathrm{N}$ and $\left.80^{\circ} 6^{\prime} 19^{\prime \prime} \mathrm{E}\right)$ and transported to Delhi in oxygenated plastic packets. Larvae were acclimated in glass aquaria and fed with live zooplankton and prepared diet (40\% protein) ad libitum twice a day. The composition of zooplankton was as follows: Brachionus calyciflorous (32.5\%), Ceriodaphnia cornuta (20.7\%), Asplanchna sp. (8.1\%) and nauplii (38.5\%). The culture units were fitted with chilling (Hailea 300, China) and a filtration unit (Sera bioactive, Germany) for the maintenance of optimum temperature $\left(18-20^{\circ} \mathrm{C}\right)$ and to reduce ammonia level in the culture unit. After 25 days larvae $(0.54 \pm 0.03 \mathrm{~g})$ were distributed randomly in glass aquaria (10 I). The stocking density was 15 larvae/ aquarium.

Three diets are formulated - control diet (diet 1, D1) without seeds and vitamin $C$ and two test diets (Table 1). In diet 2 (D2), vitamin C (L-ascorbate-2-triphosphate calcium salt, Himedia Laboratory Pvt. Ltd., Mumbai, India) was incorporated at the rate of $800 \mathrm{mg} / \mathrm{kg}$ diet; diet 3 (D3) was enriched with Achyranthes aspera seeds ( $5 \mathrm{~g} / \mathrm{kg}$ diet). Larvae were fed with one of the three diets. Three replicates were maintained for each feeding regime. The dose of vitamin C and Achyranthes aspera seeds were selected based on the previous study [33] [17] [34]. Larvae were fed twice daily at the rate of $5 \%$ of body weight. The whole amount of diet was divided into two equal amounts and was fed at 0900 hours and 1700 hours. Duration of experiment was 72 days. Survival rate, length and weight of individual larva were recorded.

Table1: Proximate composition of control and test diets of the Schizothorax richardsonii larvae.

\begin{tabular}{lccc}
\hline Ingredient $\mathrm{g} / \mathrm{kg})$ & \multicolumn{3}{c}{ Diets } \\
\cline { 2 - 4 } & $\mathrm{D} 1$ & $\mathrm{D} 2$ & $\mathrm{D} 3$ \\
\hline Dry fish powder & 583.3 & 583.3 & 583.3 \\
Wheat flour $^{\mathrm{a}}$ & 402.7 & 401.9 & 397.7 \\
Cod liver oil $^{\mathrm{b}}$ & 10.0 & 10.0 & 10.0 \\
Vitamin-mineral premixes $^{\mathrm{c}}$ & 4.0 & 4.0 & 4.0 \\
Vitamin C $^{\mathrm{d}}$ & - & 0.8 & - \\
Achyranthes aspera seeds & - & - & 5.0 \\
Proximate analysis (\% dry matter basis) & 44.63 & 42.1 & 44.63 \\
Crude protein $_{\text {Crude fat }}$ & 7.1 & 6.48 & 7.62 \\
Energy value (cal/g) & 3.60 & 3.49 & 3.68 \\
\hline
\end{tabular}

aLocal market, bSEACOD ${ }^{\circ}$, BP Universal Medicare Pvt. Ltd., Mumbai, India. 'Supradyn, Bayer Consumer Care AG, Basel Switzerland. dHiMedia Laboratories Pvt., Mumbai, India.

D1 = Control diet; D2 = Vitamin C incorporated diet; D3 = Achyranthes aspera seeds incorporated diet.

Water temperature, $\mathrm{pH}$, conductivity, total dissolved solids (TDS) and salinity of the culture units were measured using Eutech probe (PCSTestr 35, USA) and dissolved oxygen 
level through $\mathrm{HACH}\left(\mathrm{HQ} 40 \mathrm{~d}\right.$, USA). The ammonia $\left(\mathrm{NH}_{3}{ }^{+}\right)$and Nitrate $\left(\mathrm{NO}_{3}{ }^{-}\right)$concentrations in the water of the culture unit was estimated with Orion ${ }^{\mathrm{TM}}$ Versastar Probe (Thermo Scientific, USA) and nitrite $\left(\mathrm{NO}_{2}{ }^{-}\right)$was measured following the method of APHA [35].

\section{Biochemical assays Digestive enzymes}

The digestive system from individual larva was collected and tissue from five larvae was pooled to make one replicate; pooled sample was weighed and homogenized in $1 \mathrm{ml}$ of chilled distilled water ( $\mathrm{pH}$ 7.0). Three replicates were used for each parameter. The homogenate was centrifuged at $10000 \mathrm{x}$ $g$ for $30 \mathrm{~min}$ at $4^{\circ} \mathrm{C}$. The supernatant was collected for the enzyme assays. Total soluble protein was measured according to Bradford [36] with bovine serum albumin (BSA) as standard $(1 \mathrm{mg} / \mathrm{ml})$.

Amylase activity was estimated using EnzChek ${ }^{\oplus}$ Ultra Amylase Assay Kit (E33651) of Molecular Probes ${ }^{\mathrm{TM}}$ Invitrogen (Oregon, USA) at $485 \mathrm{~nm}$ (excitation) and $520 \mathrm{~nm}$ (emission) in fluorometer (Biotek Synergy H1, USA). Amylase activity was expressed as $\mathrm{U} / \mathrm{mg}$ protein/min. Molecular Probes EnzChek ${ }^{\circledast}$ Protease Assay Kits (E6638) - green fluorescence (Oregon, USA) was used to estimate total protease activity. The change in fluorescence at excitation $(485 \mathrm{~nm})$ and emission (530 nm) was recorded and activity was expressed as fluorescence change $/ \mu \mathrm{l} / \mathrm{min}$. Trypsin activity was estimated using BZ-LArg-MCA (4-methylcoumarinyl-7-amide) as substrate [37]. The change in fluorescence was recorded after 2, 4, 6 and 8 min at excitation $(380 \mathrm{~nm})$ and emission $(440 \mathrm{~nm})$ using the fluorometer at $37^{\circ} \mathrm{C}$. Trypsin activity was expressed as the

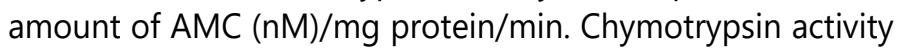
was estimated with substrate Suc-Leu-Leu-Val-Tyr-MCA (4-methylcoumarinyl-7-amide) following the method of Cao et al [38]. The fluorescence intensity from 7-amino4-methylcoumarin (AMC) liberated in the hydrolysis of substrate was measured at excitation $(380 \mathrm{~nm})$ and emission $(450 \mathrm{~nm})$. The activity was expressed as the amount of AMC $(\mathrm{nM}) / \mathrm{mg}$ protein/min. Activity of neutral lipase was determined using 4-methylumbelliferyl butyrate (4-MUB), a nonfluorescent substrate [39]. The change in fluorescence was measured at excitation $(365 \mathrm{~nm})$ and emission $(450 \mathrm{~nm})$. The lipase activity was expressed as the amount of 4-MU (nM) liberated/mg protein/min.

\section{Immunological assays}

Myeloperoxidase activity (MPO) activity in serum of larvae was estimated following the method of Quade and Roth [40]. Optical density of the reaction mixture was recorded at 450 $\mathrm{nm}$ using Microplate reader (Synergy HT, Biotek, Loveland Colorado, USA). Nitric oxide synthase (NOS) activity in the myotomes of larvae was estimated following the method of Lee et al [41]. The absorbance was recorded at $540 \mathrm{~nm}$. The nitrite concentration was expressed as $\mathrm{mol} / \mathrm{mg}$ tissue.

\section{Lipid peroxidation and stress indicators}

The concentration of thiobarbituric acid reactive substances (TBARS) in the myotomes was estimated [42]. The absorbance was recorded at $532 \mathrm{~nm}$. and the concentration was expressed as $\mu \mathrm{M} M D A / m g$ protein. Serum glutamic oxaloacetic transaminase (SGOT) and serum glutamate pyruvate transaminase (SGPT) were estimated using kits (Bayer Diagnstics, Baroda, India). The absorbance was recorded at $340 \mathrm{~nm}$ and level was expressed as IU/l.

\section{Length-weight relationship}

The length-weight relationship [43] was determined by measuring the total length $(\mathrm{cm})$ and weight of individual larva and using the log transformation equation:

$\mathrm{W}=\mathrm{a} \mathrm{L}^{\mathrm{b}}$

Where, $\mathrm{W}=$ weight of larva in $\mathrm{g}, \mathrm{L}=$ total length in $\mathrm{cm}$, a $=$ exponent describing the rate of change of weight with length (intercept of the regression line on the $Y$ axis) and $b=$ slope of the regression line or allometric coefficient.

\section{Specific growth rate, food conversion ratio and protein efficiency ratio}

Specific growth rate was calculated using the following formula:

$$
\text { SGR }(\%)=\frac{(\ln \text { final weight of fish }-\ln \text { initial weight of fish }) \times 100}{\text { Duration of experiment }}
$$

Food conversion ratio $(F C R)$ was calculated using the formula:

$$
F C R=\frac{\text { Total weight of the feed consumed }(g)}{\text { Total weight gain of the fish }(g)}
$$

The protein efficiency ratio (PER) was evaluated to quantify the nutritional value of diets using the formula:

$$
\text { PER }=\frac{\text { Total wet weight gain }(g)}{\text { Dry weight of protein in diet }(g)}
$$

\section{Statistical analysis}

Results were given as mean \pm SE One-way analysis of variance (ANOVA) and regression analyses were performed for various parameters. Statistical significance was accepted at $P<0.05$ level.

\section{Results}

\section{Water quality parameters}

Water quality parameters viz. temperature, $\mathrm{pH}$, dissolved oxygen, ammonia, and nitrites were not significantly $(P>$ 0.05) different among treatments throughout the study period. Water temperature ranged from $18.7-21.8^{\circ} \mathrm{C}$ in various days of culture in three different feeding regimes. $\mathrm{pH}$ ranged from 7.6 - 7.9, 7.67 - 7.9 and $7.56-7.87$ in D1, D2 and D3 treatments, respectively during the study period. Dissolved oxygen levels were $7.8 \pm 0.05,7.7 \pm 0.14$ and $7.71 \pm 0.06 \mathrm{mg} / \mathrm{l}$ in D1, D2 and D3, respectively. Ammonia concentrations were $0.14 \pm 0.01,0.10 \pm 0.06$ and $0.10 \pm 0.02 \mathrm{mg} / \mathrm{l}$ in D1, D2 and 
D3, respectively during the study period. Nitrite levels were $0.61 \pm 0.05,0.60 \pm 0.04,0.62 \pm 0.20 \mathrm{mg} / \mathrm{l}$ and nitrate levels were $0.11 \pm 0.02,0.10 \pm .01,0.09 \pm 0.01 \mathrm{mg} / \mathrm{l}$ in D1, D2 and D3, respectively during the culture period.

\section{Performance of larva}

There was no significant $(P>0.05)$ difference in the survival rate of larvae cultured under three different feeding regimes. Survival rates were $91 \pm 1,93 \pm 1$ and $93 \pm 1 \%$ in D1, D2 and D3, respectively. The average weight of larvae was significantly $(P<0.05)$ higher in fish feed with Achyranthes aspera seeds supplemented diet (D3) compared to others (Table 2). The length and weight relationship of snow trout larvae cultured in three different feeding regimes showed close $R^{2}$ values (D1: 0.959, D2: 0.961 and D3: 0.971). The allometric coefficient value " $b$ " was 2.872, 2.67 and 2.74 for D1, D2 and D3, respectively. Significantly $(P<0.05)$ higher specific growth rate and protein efficiency ratio were found in larvae fed with diet D3 compared to others. FCR value was significantly $(P<0.05)$ lower in larvae fed with diet D3 compared to other two feeding regimes (Table 2).

Table 2: Growth and feed efficiency parameters of Schizothorax richardsonii larvae. Values are represented as Mean \pm SE $(n=3)$.

\begin{tabular}{llll}
\hline Parameters & \multicolumn{3}{c}{ Diets } \\
\cline { 2 - 4 } & \multicolumn{1}{c}{$\mathrm{D} 1$} & \multicolumn{1}{c}{$\mathrm{D} 2$} & \multicolumn{1}{c}{$\mathrm{D} 3$} \\
\hline Final length $(\mathrm{cm})$ & $5.06 \pm 0.10$ & $5.18 \pm 0.32$ & $5.72 \pm 0.51$ \\
Final weight $(\mathrm{g})$ & $1.035 \pm 0.03$ & $1.318 \pm 0.16$ & $1.57 \pm 0.02$ \\
$\mathrm{R}^{2}$ & 0.959 & 0.961 & 0.971 \\
$\mathrm{~b}$ & 2.872 & 2.699 & 2.738 \\
$\mathrm{~K}(\mathrm{~g} / \mathrm{cm})$ & $0.983 \pm 0.02$ & $1.634 \pm 0.26$ & $1.324 \pm 0.04$ \\
PER $(\%)$ & $0.508 \pm 0.01$ & $0.948 \pm 0.12$ & $1.25 \pm 0.16$ \\
SGR $(\% / \mathrm{d})$ & $0.828 \pm 0.04$ & $1.23 \pm 0.2$ & $1.53 \pm 0.5$ \\
FCR & $3.12 \pm 1.04$ & $1.9 \pm 0.10$ & $1.44 \pm 0.12$ \\
\hline
\end{tabular}

$\mathrm{R}^{2}=$ Coefficient of determination; $\mathrm{b}=$ Slope; $\mathrm{K}=$ Condition factor; $\mathrm{PER}=$ Protein efficiency ratio; $S G R=$ Specific growth rate; $F C R=$ Feed conversion ratio; D1 = Control diet; D2 = Vitamin C incorporated diet; D3 = Achyranthes aspera seeds incorporated diet.

\section{Biochemical assays}

Amylase, total protease, trypsin and lipase activities were significantly $(P<0.05)$ higher in larvae fed with D3 diet compared to other feeding regimes. Chymotrypsin activity was significantly $(P<0.05)$ higher in fish fed with vitamin $C$ supplemented diet compared to others. This group was followed by D3 diet fed larvae (Table 3).

Myeloperoxidase and nitric oxide synthase levels were significantly $(P<0.05)$ higher in larvae fed with vitamin $C$ and Achyranthes aspera seeds supplemented diets compared to the control diet fed larvae. There was no significant $(P>0.05)$ difference in nitric oxide synthase level in larvae fed with $D 2$ and D3 diets. Thiobarbituric acid reactive substances level was significantly $(P<0.05)$ lower in larvae fed with diet D3 compared to others. SGOT level was minimum in D2 diet fed larvae (Table 3). There was no significant $(P>0.05)$ difference in SGOT level in larvae fed with D1 and D3 diets. There was no significant $(P$ $>0.05$ ) difference in SGPT level in different diets fed larvae.
Table 3: Digestive enzyme activities, immunological, lipid peroxidation, SGOT and SGPT levels of Schizothorax richardsonii larvae cultured in three different feeding regimes. Values are represented as Mean $\pm S E(n=3)$.

\begin{tabular}{|c|c|c|c|}
\hline \multirow[t]{2}{*}{ Parameters } & \multicolumn{3}{|c|}{ Diets } \\
\hline & D1 & D2 & D3 \\
\hline \multicolumn{4}{|l|}{ Digestive enzymes } \\
\hline $\begin{array}{l}\text { Amylase } \\
\text { (U/mg protein/min) }\end{array}$ & $17.25 \pm 0.04$ & $17.73 \pm 0.04$ & $27.36 \pm 0.06$ \\
\hline $\begin{array}{l}\text { Total protease } \\
\text { (Fluorescence change/ } \mathrm{\mu l} / \\
\mathrm{min} \text { ) }\end{array}$ & $706.26 \pm 34.23$ & $731.06 \pm 29.4$ & $848.25 \pm 29.34$ \\
\hline $\begin{array}{l}\text { Trypsin } \\
\text { (nM AMC/mg protein/min) }\end{array}$ & $3600.86 \pm 13.16$ & $4345.33 \pm 40.5$ & $7714.61 \pm 46.1$ \\
\hline $\begin{array}{l}\text { Chymotrypsin } \\
\text { (nM AMC/mg protein/min) }\end{array}$ & $4691.68 \pm 80.03$ & $6315.6 \pm 41.4$ & $5353.28 \pm 43.9$ \\
\hline $\begin{array}{l}\text { Neutral lipase } \\
\text { (nM MUB/mg protein/min) }\end{array}$ & $965.82 \pm 57.8$ & $1338.1 \pm 33.3$ & $1398.58 \pm 93.8$ \\
\hline \multicolumn{4}{|l|}{ Immunological parameters } \\
\hline $\begin{array}{l}\text { Myloperoxidase } \\
(\mathrm{OD} \text { at } 450 \mathrm{~nm})\end{array}$ & $1.616 \pm 0.38$ & $2.419 \pm 0.01$ & $2.808 \pm 0.08$ \\
\hline $\begin{array}{l}\text { Nitric oxide synthase } \\
\text { (mol/mg tissue) }\end{array}$ & $72.128 \pm 3.36$ & $107.13 \pm 7.95$ & $104.003 \pm 4.57$ \\
\hline \multicolumn{4}{|c|}{ Lipid peroxidation and stress indicators } \\
\hline $\begin{array}{l}\text { Thiobarbituric reactive } \\
\text { substances } \\
\text { ( } \mu \mathrm{M} \mathrm{MDA} / \mathrm{mg} \text { protein) }\end{array}$ & $23.54 \pm 1.8$ & $13.85 \pm 0.85$ & $5.82 \pm 1.44$ \\
\hline $\begin{array}{l}\text { Serum glutamate oxalate } \\
\text { transaminase (SGOT, IU/I) }\end{array}$ & $64.78 \pm 0.05$ & $57.93 \pm 0.02$ & $62.71 \pm 0.13$ \\
\hline $\begin{array}{l}\text { Serum glutamate pyruvate } \\
\text { transaminase (SGPT, IU/I) }\end{array}$ & $59.99 \pm 0.18$ & $58.01 \pm 0.43$ & $58.63 \pm 0.14$ \\
\hline
\end{tabular}

\section{Discussion}

In the present study, supplementation of vitamin $C$ and Achyranthes aspera seeds resulted in better performance of larvae compared to the control diet fed larvae. Vitamin $\mathrm{C}$ has been identified as a very essential nutrient for fish since the only source of vitamin C in the fish's body is through the diet [44]. The essentiality of vitamin $C$ as nutrient for optimum growth and maintenance [45] [46] and its role in certain aspects of protein metabolism [47] are also reflected in FCR, PER and SGR values in present study. Supplementation of vitamin $C$ in fish feed resulted in better survival and growth of tilapia Oreochromis spirulus [48], yellow croaker Pseudociaena crocea [49] and parrot fish Oplegnathus fasciatus [13]. The overall well being of fish fed with different diets was assessed through the length-weight relationship. Goel et al [50] ascribed that the ideal b value of Schizothorax richardsonii as 2.68. In the present study, $b$ value ranged from $2.67-2.87$. This showed the optimum culture conditions were maintained for this species.

Supplementation of seeds of Achyranthus aspera in diets enhanced survival, growth and feed utilization in rohu [17] [34] and common carp [23]. Higher growth rate in D3 diet fed snow trout was due to the presence of highly nutritive value of ingredients and presence of bioactive molecules like oleanolic acid, bis-desmosidic-triterpinoid-based saponins, ecdysterone and various amino acids in the seeds [51] [52]. 
Ecdysterone is reported to have pronounced growthpromoting effect due to high rate of protein synthesis [53]. In common carp, enhanced growth rate was recorded due to the presence of ecdysterone in the diet compared to the control diet fed fish [23].

The efficiency of food absorption and conversion also depend on the availability of digestive enzymes or on the capacity for trans-epithelial transport in the digestive tract [54]. A positive correlation was found between trypsin and chymotrypsin activities and FCR in striped bass Morone saxatilis [55], Atlantic cod Gadus morhua [56] and in Atlantic salmon Salmon salar [57]. Similar relationship was also found between the trypsin activity and FCR in the present study. Trypsin activity was reported to relate with growth rate of larvae of goldfish Carassius auratus L [58] and sea bass Dicentrarchus labrax [59] fed with high quality diets. In addition, the difference in trypsin activity level may have indirect effect on the immune system as it affects variations in nutrient influx [60], and dietary nutrients play important roles in relation to the immune function of fish [61].

Immunostimulants activate non-specific defence mechanisms to protect the fish against pathogens [62]. Snow trout larvae fed with vitamin $C$ and Achyranthus aspera seeds supplemented diets showed significantly higher nitric oxide synthase and myeloperoxidase levels compared to the control diet fed larvae. Elevated NOS and MPO levels indicated prophylactic measure of the larvae against possible pathogen attack. Feeding of curcumin Curcuma longa to rohu [63] and levamisole to catla [64] and catfish Clarias batrachus [65] resulted in enhanced MPO level. This was an indication of positive non-specific immune response. According to Anderson and Siwicki [66], reduction of MPO activity was considered as stress in fish. The inducible isoform iNOS of nitric oxide synthase catalyze the production of cellular signalling molecule nitric oxide [67]. Higher level of nitric oxide synthase in catla [21], rohu [23] and common carp [22] was indicator of better immune system.

The source of dietary energy modulates lipid oxidation in muscle homogenates of rainbow trout and sea bass [68] [69] [70]. Supplementation of vitamin C and seeds of Achyranthes aspera in diets showed less lipid peroxidation compared to the control diet fed snow trout. Insignificant difference in SGOT and SGPT levels in snow trout larvae fed with different diets suggested the absence of challenge/ stress in the culture system. Higher levels of these enzymes indicated poor physiological status of the organism.

\section{Conclusions}

In conclusions, supplementation of vitamin $C$ and seeds of Achyranthes aspera in diet enhanced the survival, growth and improved the digestive physiology of snow trout larvae. It also boosted the immune system of larvae.

\section{Conflict of interest}

The authors have declared no conflict of interest.

\section{Acknowledgements}

Authors are thankful to the Royal Norwegian Embassy, Kathmandu, for providing financial support to this project. M.R. is thankful to University Grants Commission for providing him Teacher Fellowship. We thank Dr. Suresh Chandra, Dr. P. Srivastava and all technical staffs of Directorate of Cold Water Fisheries, Champawat for their cordial support.

\section{References}

1. Agarwal NK, Thapliyal BL, Raghuvanshi SK. Induced breeding and artificial fertilization of snow trout, Schizothorax richardsonii through the application of ovaprim. J Inland Fish Soc India. 2007; 39: 12-19.

2. Agarwal NK, Raghuvanshi SK, Saini V, Rawat US. Milt quality and short term storage of snow trout (Schizothorax richardsonii) sperm. J Inland Fish Soc India. 2004; 36: 13-18.

3. Joshi KD. Artificial breeding and rearing of Schizothorax richardsonii (Gray). Indian J Fish. 2004; 51: 233-237.

4. Joshi CB, Sunder S. Breeding and culture of snow-trout, Schizothorax richardsonii (Gray) in Kumaon Himalayas. Uttar Pradesh. J Zool Soc India. 1995; 15: 136-140.

5. Raina HS, Sunder S, Vass KK, Langer RK. Artificial breeding and nursery rearing of Schizothoraichthys esocinus (Heckel). Proc Natl Acad Sci India. 1986; 56B: 335-338.

6. Mir Jl, Shabir R, Mir FA. Length-weight relationship and condition factor of Schizopyge curvifrons (Heckel, 1838) from River Jhelum, Kashmir, India. World J Fish Mar Sci. 2012; 4(3): 325-329.

7. Lall SP, Olivier $\mathrm{G}$. Role of micronutrients in immune response and disease resistance of fish. In: Kaushik SJ, Luquet $\mathrm{P}$, eds., Fish Nutrition in Practice. National Institute for Agricultural Research, Paris, France. 1993; 101-118.

8. Sato $P$, Nishikimi $M$, Udenfriend $S$. Is gulonolactone-oxidase the only enzyme missing in animals subject to scurvy? Biochem Biophys Res Commun. 1976; 71(1): 293-299. doi: 10.1016/0006-291x(76)90281-3

9. Eo J, Lee K. Effect of dietary ascorbic acid on growth and nonspecificimmune responses of tiger puffer, Takifugu rubripes. Fish Shellfish Immunol. 2008; 25(5): 611-616. doi: 10.1016/j.fsi.2008.08.009

10. Tewary A, Patra BC. Use of vitamin C as an immunostimulant. Effect on growth, nutritional quality, and immune response of Labeo rohita (Ham.). Fish Physiol Biochem. 2008; 34(3): 251-259. doi: 10.1007/s10695-007-9184-z

11. Masumoto $T$, Hidetuyo $H$, Shimeno $S$. Ascorbic acid's role in aquaculture nutrition. Proceedings of the aquaculture feed processing and nutrition Workshop, American Soybean Association, Indonesia. 1991: 42-48.

12. Chaterjee IB. Ascorbic acid metabolism. World Rev Nutr Diet. 1978; 30: 69-87.

13. Wang X, Kim K, Bai SC, Huh M, Cho B. Effects of the different levels of dietary vitamin $C$ on growth and tissue ascorbic acid changes in parrot fish (Oplegnathus fasciatus). Aquaculture. 2003; 215(1-4): 203-211. doi: 10.1016/S0044-8486(02)00042-x

14. Zhou Q, Wang L, Wang $H$, Xie F, Wang $T$. Effect of dietary vitamin $C$ on the growth performance and innate immunity of juvenile cobia (Rachycentron canadum). Fish Shellfish Immunol. 2012; 32(6): 969-975. doi: 10.1016/j.fsi.2012.01.024

15. Dabrowski K, El-Fiky N, Köch G, Frigg M, Wieser W. Requirement and utilization of $\mathrm{AA}$ and ascorbic acid sulphate in juvenile rainbow trout. Aquaculture. 1990; 91(3-4): 317-337. doi: 10.1016/0044-8486(90)90197-U

16. Xie Z, Niu C, Zhang Z, Bao L. Dietary ascorbic acid may be necessary for enhancing the immune response in Siberian sturgeon (Acipenser baerii), a species capable of ascorbic acid biosynthesis. Comp Biochem Physiol A Mol Integr Physiol. 2006; 145(2): 152-157. doi: 10.1016/j.cbpa.2006.05.015

17. Singh MK, Sharma JG, Chakrabarti R. Impact of UV-B radiation on the physiology of freshwater carp Labeo rohita larvae and evaluation of UV-B protective properties of seeds of Achyranthes aspera and vitamin C. Agric Res. 2013; 2: 166-171. doi: 10.1007/s40003-013-0060-z 
18. Findlay VL, Munday BL. The immunomodulatory effects of levamisole on the nonspecific immune system of Atlantic salmon, Salmo salar L. J Fish Dis. 2000; 23(6): 369-378. doi: 10.1046/j.1365-2761.2000.00231.x

19. Girach RD, Khan ASA. Ethnomedicinal uses of Achyranthes aspera leaves in Orissa (India). Int J Pharm. 1992; 30: 113-115.

20. Liersch BKHR. Achyranthes. In: Haensel R, Keller K, Rimpler H, Schneider G, eds., Hagers handbuch der pharmazeutischen praxis, Berlin. 1992: 54-59.

21. Rao VY, Chakrabarti R. Stimulation of immunity in Indian major carp Catla catla with herbal feed ingredients. Fish Shellfish Immunol. 2005; 18(4): 327-334. doi: 10.1016/j.fsi.2004.08.005

22. Chakrabarti R, Srivastava PK, Kundu K, Khare RS, Banerjee S. Evaluation of immunostimulatory and growth promoting effect of seed fractions of Achyranthes aspera in common carp Cyprinus carpio and identification of active constituents. Fish Shellfish Immunol. 2012; 32(5): 839-843. doi: 10.1016/j.fsi.2012.02.006

23. Chakrabarti R, Srivastava PK. Effect of dietary supplementation with Achyranthes aspera seed on larval rohu Labeo rohita challenged with Aeromonas hydrophila. J Aquat Anim Health. 2012; 24(4): 213-218. doi: 10.1080/08997659.2012.694834

24. Basade $M$, Mohan $M$. Experimental cage culture of snow trout, Schizothorax richardsonii (Gray) and golden mahseer, Tor putitora (Hamilton) fry and fingerlings in a Sub-Himalayan Lake Bhimtal, India. Indian J Anim Sci. 2012; 82: 1106.

25. Jha GN, Dar BA, Jha T, Sarma D, Qureshi TA. Effect of Spirulina and apple peel meal on growth performance, body composition and total carotenoids of snow trout (Schizothorax richardsonii). Indian J Anim Nutr. 2013; 30(4): 404-409.

26. Jha GN, Sarma D, Qureshi TA, Akhtar MS. Effect of marigold flower and beetroot meals on growth performance, carcass composition, and total carotenoids of snow trout (Schizothorax richardsonii). Isr J Aquacult Bamidgeh. 2012.

27. Mohan M, Bhanja SK, Basade Y. Performance of chitin incorporated diet on the indigenous Kumaon Himalayan fishes: snow trout, Schizothorax richardsonii (Gray) and golden mahseer, Tor putitora (Hamilton). Indian J. Fish. 2009; 56(2): 135-137.

28. Joshi KD. Brood-stock rearing and artificial breeding of Schizothorax richardsonii (Gray). J Inland Fish Soc India. 2006; 38(1): 64-67.

29. Houde ED. Patterns and consequences of selective processes in teleost early life histories. In: Chambers RC, Trippel EA, eds., Early Life History and Recruitment in Fish Populations. Chapman and Hall, London, UK. 1997: 173-196.

30. Houde ED. Comparative growth, mortality and energetics of marine fish larvae: temperature and implied latitudinal effects. Fish Bull. 1989; 87(3): 471-495.

31. Adhikari S, Sarkar B, Chatterjee A, Mahapatra CT, Ayyappan S. Effects of cypermenthrin and carbofuran on certain haematological parameters and prediction of their recovery in a freshwater teleost, Labeo rohita (Hamilton). Ecotoxicol Environ Saf. 2004; 58(2): 220-226. doi: 10.1016/j. ecoenv.2003.12.003

32. Srivastava PK, Chakrabarti R. Effect of dietary supplementation of seed of Achyranthes aspera on the immune system of Labeo rohita fry. Israeli J Aquacult Bamidgeh. 2012

33. Chakrabarti R, Labh SN. Effects of vitamin C (L-ascorbate 2-triphosphate calcium) on the growth, biochemical composition, and tissue ultrastructure of hybrid carp. In: Hendry Cl, Stappen GV, Wille M, Sorgeloos P, eds., Larvi'09 - Fish and Shellfish Larviculture Symposium. European Aquaculture Society, Oostende, Belgium, 2009; 38: 41-44.

34. Singh MK, Sharma JG, Chakrabarti R. Effect of UV-B radiation on the defence system of Labeo rohita (Actinopterygii: Cypriniformes: Cyprinidae) larvae and its modulation by seed of devil's horsewhip, Achyranthes aspera. Acta Ichthyol Pisc. 2013; 43(2): 119-126.

35. APHA. Standard Methods for the Examination of Water and Wastewater. 22nd ed. American Public Health Association, Washington, DC, USA. 2012; 4: 122-123.
36. Bradford MM. A rapid and sensitive method for the quantitation of microgram quantities of protein utilizing the principle of protein-dye binding. J Anal Biochem. 1976; 72(1-2): 248-254. doi: 10.1016/00032697(76)90527-3

37. Ueberschär B. Determination of the nutritional condition of individual marine fish larvae by analyzing their proteolytic enzyme activities with a highly sensitive fluorescence technique. Meeresforschung. 1988; 32: 144154.

38. Cao MJ, Osatomi K, Suzuki M, Hara K, Tachibana K, and et al. Purification and characterization of two anionic trypsins from the hepatopancreas of carp. Fisheries Sci. 2000; 66(6): 1172-1179. doi: 10.1046/j.1444-2906.2000.00185.x

39. Roberts IM. Hydrolysis of 4-methylumbelliferyl butyrate: a convenient and sensitive fluorescent assay for lipase activity. Lipids. 1985; 20: 243247. doi: $10.1007 / B F 02534195$

40. Quade MJ, Roth JA. A rapid, direct assay to measure degranulation of bovine neutrophil primary granules. Vet Immunol Immunop. 1997; 58(34): 239-248. doi: 10.1016/\$0165-2427(97)00048-2

41. Lee DU, Kang YJ, Park MK. Effect of 13-alkyl-substituted berberine alkaloids on expression of COX-II, TNF- $\alpha$, iNOS and IL-12 production in LPS stimulated macrophages. Life Sci. 2003; 73(11): 1401-1412. doi: 10.1016/S0024-3205(03)00435-1

42. Ohkawa $\mathrm{H}$, Ohishi $\mathrm{N}$, Yagi K. Assay for lipid peroxides in animal tissues by thiobarbituric acid reaction. Anal Biochem. 1979; 95: 351-358. doi: 10.1016/0003-2697(79)90738-3

43. Le'Cren ED. The length-weight relationship and seasonal cycle in gonad weight and condition in the perch Perca fluviatilis. J Anim Ecol. 1951; 20(2): 201-219. doi: 10.2307/1540

44. Fracalossi DM, Allen ME, Yuyama LK, Oftedal OT. Ascorbic acid biosynthesis in Amazonian fishes. Aquaculture. 2001; 192(2-4): 321-332. doi: 10.1016/S0044-8486(00)00455-5

45. Dabrowski K, Matusiewicz M, Hoppe PP, Ebling J. Bioavailability of vitamin C from two ascorbyl monophosphate esters in rainbow trout, Oncorhynchus mykiss (Walbaum). Aquacult Nutr. 1996; 2(1): 3-10. doi: 10.1111/j.1365-2095.1996.tb00002.x

46. Lovell RT. Essentiality of vitamin $C$ in feeds for intensively fed caged channel catfish. J Nutr. 1973; 103(1): 134-138.

47. Shiau SY, Jans FI. Dietary ascorbic acid requirement of juvenile tilapia Oreochromis niloticus x O. aureus. Nippon Suisan Gakk. 1992; 58: 671675.

48. Al-Amoudi MM, El-Nakkadi AMN, El-Nouman BM. Evaluation of optimum dietary requirement of vitamin C for the growth of Oreochromis spilurus fingerlings in water from the Red Sea. Aquaculture. 1992; 105(2): 165-173. doi: 10.1016/0044-8486(92)90128-8

49. Ai Q, Mai K, Tan B, Xu W and et al. Effects of dietary vitamin C on survival, growth, and immunity of large yellow croaker, Pseudosciaena crocea. Aquaculture. 2006; 261(1): 327-336. doi: 10.1016/j.aquaculture.2006.07.027

50. Goel C, Barat A, Pande V, Ali S, Kumar R. Length-weight relationship of snow trout (Schizothorax richardsonii) based on linear and nonlinear models from the hill stream of Uttarakhand, India. World J Fish Mar Sci. 2011; 3: 485-488.

51. Banerji A, Chintalwar GT, Joshi NK, Chadha MS. Isolation of ecdysterone from Indian plants. Phytochemistry. 1971; 10(9): 2225-2226. doi: 10.1016/ S0031-9422(00)97227-3

52. Varuna KM, Khan MU, Sharma PK. Review on Achyranthes aspera. J Pharm Res. 2010; 3: 714-717.

53. Goerlick-Feldman J, MacLean D, llic N, Poulev A, Lila MA and et al. Phytoecdysteroids increases protein synthesis in skeletal muscle cells. J Agric Food Chem. 2008; 56: 3532-3537. doi: 10.1021/jf073059z

54. Jobling M. Environmental Biology of Fishes. Chapman and Hall, London, UK. 1995: 175-210.

55. Baragi V, Lovell RT. Digestive enzyme activities in striped bass from first feeding through larva development. Trans Am Fish Soc. 1986; 115(3): 478-484. doi: 10.1577/1548-8659(1986)115 
56. Lemieux $H$, Blier P, Dutil JD. Do digestive enzymes set a physiological limit on growth rate and food conversion efficiency in Atlantic cod (Gadus morhua)? Fish Physiol Biochem. 1999; 20: 293-303. doi: 10.1023/A:1007791019523

57. Sunde J, Taranger GL, Rungruangsak-Torrissen K. Digestive protease activities and free amino acids in white muscle as indicators for feed conversion efficiency and growth rate in Atlantic salmon (Salmo salar L.). Fish Physiol Biochem. 2001; 25: 335-345. doi: 10.1023/A:1023233024001

58. Abiayad A, Kestemont P. Comparison of the nutritional status of goldfish (Carassius auratus) larvae fed with live, mixed or dry diet. Aquaculture. 1994; 128: 163-176. doi: 10.1016/0044-8486(94)90111-2

59. Nolting $\mathrm{M}$, Ueberschar $\mathrm{B}$, Rosenthal $\mathrm{H}$. Trypsin activity and physiological aspects in larval rearing of European sea bass (Dicentrarchus labrax) using live prey and compound diets. J Appl Ichthyol. 1999; 15: 138-142. doi: 10.1046/j.1439-0426.1999.00138.x

60. Rungruangsak-Torrissen K, Wergeland HI, Glette J, Waagbø R. Disease resistance and immune parameters in Atlantic salmon (Salmo salar L.) with genetically different trypsin isozymes. Fish. Shellfish. Immunol. 1999; 9(7): 557-568. doi: 10.1006/fsim.1999.0214

61. Waagbø R. The impact of nutritional factors on the immune system in Atlantic salmon, Salmo salar L.: a review. Aquaculture. Res. 1994; 25(2): 175-197. doi: 10.1111/j.1365-2109.1994.tb00573.x

62. Siwick AK, Anderson DP, Rumsey GL. Dietary intake of immunostimulants by rainbow trout affects non-specific immunity and protection against furunculosis. Vet Immunol Immunop. 1994; 41(1-2): 125-139.

63. Behera T, Swain P, Sahoo SK, Mohapatra D, Das BK. Immunostimulatory effects of curcumin in fish, Labeo rohita $(\mathrm{H}$.). Indian J Nat Prod Resour. 2011; 2: 184-188.
64. Perera HACC, Pathiratne A. Enhancement of immune responses in Indian carp, Catla catla, following administration of levamisole by immersion. In: Bondad-Reantaso MG, Mohan CV, Crumlish M, Subasinghe RP, eds., Diseases in Asian Aquaculture VI. Fish Health Section, Asian Fisheries Society, Manila, Philippines. 2008: 129-142.

65. Kumari J, Sahoo PK. Dietary levamisole modulates the immune response and disease resistance of Asian catfish Clarias batrachus (Linnaeus). Aquacult.Res.2006;37(5):500-509.doi:10.1111/j.1365-2109.2006.01456.x

66. Anderson DP, Siwicki AK. Basic haematology and serology for fish health programs. In: Shariff M, Authur JR, Subasinghe RP, eds., Diseases in Asian Aquaculture II. Fish Health Section. Asian Fisheries Society, Manila, Philippines. 1995: 185-202.

67. Villamil L, Tafalla C, Figueras A, Novoa B. Evaluation of immunomodulatory effects of lactic acid bacteria in turbot (Scophthalmus maximus). J Clin Diagn Lab Immunol. 2002; 9: 1318-1323. oi: 10.1128.CDLI.9.6.13181323.2002

68. Alvarez MJ, Lopez-Bote CJ, Diez A, et al. The partial substitution of digestible protein with gelatinized starch as an energy source reduces susceptibility to lipid oxidation in rainbow trout (Oncorhynchus mykiss) and sea bass (Dicentrarchus labrax) muscle. J Anim Sci. 1999; 77(12): 3322-3329.

69. Alvarez MJ, Lopez-Bote CJ, Diez A et al. Dietary fish oil and digestible protein modify susceptibility to lipid peroxidation in the muscle of rainbow trout (Oncorhynchus mykiss) and sea bass (Dicentrarchus labrax). Br J Nutr. 1998; 80(3): 281-289.

70. Lopez-Bote CJ, Diez A, Corraze G et al. Dietary protein source affects the susceptibility to lipid peroxidation of rainbow trout (Oncorhynchus mykiss) and sea bass (Dicentrarchus labrax) muscle. J Anim Sci. 2001; 73(3): 443-449. doi: 10.1017/S1357729800058410 